\title{
Chapter 16 \\ Ecological Roles of Railway Verges in Anthropogenic Landscapes: A Synthesis of Five Case Studies in Northern France
}

\author{
J.-C. Vandevelde and C. Penone
}

\begin{abstract}
This chapter presents the results of several studies realised between 2010 and 2014 on the French railway network. We assessed several potential ecological roles for this network on various taxa: (1) habitat, (2) corridor/longitudinal connectivity along railways and (3) barrier/transversal connectivity across railways. Our results show that railway verges, contrary to common belief, can have positive effects in anthropogenic landscapes for several taxa and communities. They can be habitats for semi-natural grassland plants, bats and orthopteran. They provide functional connectivity for some plants, but do not seem to increase it for highly mobile invasive species in urban landscapes. Railways also seem to be weaker barriers than roads for one butterfly species. We conclude by proposing a change in management practices, stressing that extensive management coupled with small-scale revegetation processes, either artificial or natural, may help increase the positive effects of railway verges and counteract the negative large-scale effects of urbanisation.
\end{abstract}

Keywords Habitat - Corridor • Barrier - Agricultural landscape - Urban landscape $\cdot$ Bat $\cdot$ Orthoptera $\cdot$ Plant $\cdot$ Butterfly $\cdot$ Railway verges management

\section{Introduction}

Changes in land-use are important drivers of biodiversity loss (MEA 2005). Linear infrastructures such as roads and railways play a particular role in this process by altering, artificializing and fragmenting landscapes (see previous chapters).

\footnotetext{
J.-C. Vandevelde $(\square)$

UMR 7204 (MNHN-CNRS-UPMC), Centre d'Ecologie et de Sciences de la Conservation (CESCO), 43 rue Buffon, 75005 Paris, France

e-mail: vandeveldejeanchristophe@gmail.com

C. Penone

Institute of Plant Sciences, University of Bern,

Altenbergrain 21, 3013 Bern, Switzerland

(C) The Author(s) 2017

L. Borda-de-Água et al. (eds.), Railway Ecology,

DOI 10.1007/978-3-319-57496-7_16
} 
Nonetheless, linear infrastructure verges can also have positive roles for a large number of taxa (Hodkinson and Thompson 1997; Merriam and Lanoue 1990). They can be substitution habitats for grassland plants and insects (Saarinen et al. 2005; Wehling and Diekmann 2009), hence contribute to the conservation of indigenous flora (O'Farrell and Milton 2006) and fauna (Ries et al. 2001). They can also ensure structural and functional connectivity when they penetrate artificial areas such as dense urban areas or agricultural-intensive landscapes (Tikka et al. 2001).

Among studies examining the effects of linear infrastructure verges, very few focused on railway verges, the majority concerning roadside verges (Forman et al. 2002). Indeed, compared to roadside verges, railway verges occupy smaller surfaces. Nevertheless, railway verges have at least two peculiarities worth considering when compared to roadside verges. First, their potential positive effects on biodiversity may be significant in human-dominated areas such as intensive agricultural or urban landscapes due to their greater width margins and lower traffic intensity. Second, railway lines of many European countries are managed by one unique manager, allowing realistic biodiversity-friendly management (see discussion).

This chapter presents the results of five studies realised between 2009 and 2014 on the French railway network. We assessed three potential ecological roles for this network: (1) habitat, (2) corridor/longitudinal connectivity along the railway and (3) barrier/transversal connectivity across the railway.

\section{General Context and Methodology}

We conducted five different studies in the Paris region, France (Fig. 16.1). Although densely populated, with $20 \%$ of the national population living in just $2 \%$ of the nation's land area, and with a spreading urbanisation, the Paris region is still predominantly rural. Intensive farming covers $50 \%$ of the regional territory, woods and natural land more than $25 \%$, and urban areas and transport infrastructures cover about $25 \%$.

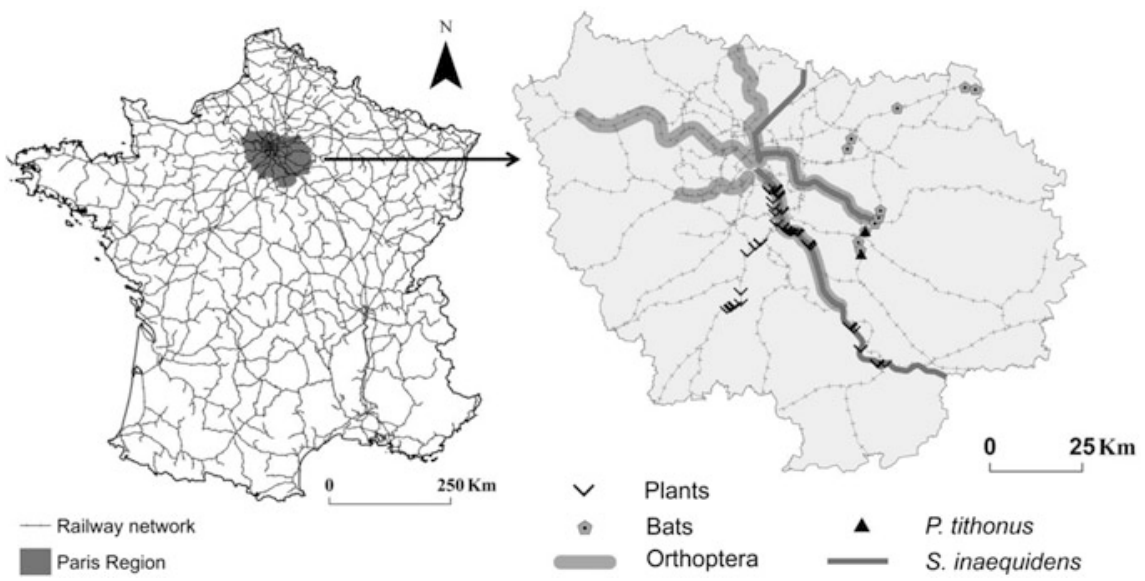

Fig. 16.1 Location of study sites in France (left panel) and in the Paris region (right panel) 


\section{Vegetation of railway verges in France}

The studies described in this chapter were conducted along railway verges. Railway verges are all the green areas that are beside the railway tracks. The total area occupied by railway verges in France is estimated by the railway owner, the SNCF Réseau company, at 50000 hectares. The vegetation type on these green spaces is dictated by security reasons. Management is thus necessary but different in different parts of the railway concerned:

- Tracks and lanes: the goal is the absence of vegetation to avoid platform/ infrastructure deterioration. Total weed control is recommended once a year but depends on the age of the infrastructure. For instance, a recent track, better drained, is less sensitive to plant colonization and is usually not treated for 10 year;

The verges can be separated in two main zones:

- The first zone is adjacent to the tracks and has variable width depending on the slope and surrounding landscape. Here the objective is to have an herbaceous vegetation to allow visibility and limit fire problems. These semi-natural grasslands are ideally managed by annual or multi-annual mowing depending on fire risks and on potential recolonisation by woody species;

- In the second zone, the desired vegetation can be higher depending on their configuration: if the verge is lower compared to the tracks (fill section), the trees and shrubs are allowed to grow higher compared to a configuration where the verges are higher than the tracks (cut section). Management here does not need to be intensive and can be done every 3-5 years depending on the slope and the vegetation in the surrounding landscape.

We examined two types of railways: recently built high-speed railway lines (1994 and 2007) and long-established railway lines (built in the nineteenth century). In the high-speed lines, we studied verges from 10 to $20 \mathrm{~m}$-wide, composed of herbaceous species and shrubs. No vegetation management plan existed for these verges. Clearcutting of trees and mowing were applied on a case-by-case basis when presenting threats for train security, e.g. risk of tree falling on overhead lines. The long-established lines traverse a landscape structured by different degrees of urbanisation, as they cross numerous cities and towns from the centre of Paris towards the limits of the region. The vegetation found along the borders of the train tracks is mainly spontaneous as the verges have not been planted or sown since their construction and is principally interrupted by railway stations and overpasses.

\section{Roles of Railway Verges: Habitat, Corridor, Barrier}

\section{Railways as Habitats}

Linear infrastructures can be substitution habitats for various taxa (O'Farrell and Milton 2006; Ries et al. 2001), however, hardly any studies focused properly on 
railways. We thus decided to examine the role of railway verges as a habitat for two groups: common bats and Tettigoniidae (Orthoptera) (Vandevelde et al. 2014; Penone et al. 2013).

\section{Bats Along Railway Verges in an Intensive Agricultural Landscape}

Studies have shown that bat activity and species richness decrease when approaching a motorway (Berthinussen and Altringham 2012). Some studies stressed particular negative effects, such as road casualties (Lesinski et al. 2011). Others found that roads formed strong barriers to the movements of bats within the landscape (Bach et al. 2004; Kerth and Melber 2009; Abbott et al. 2012).

Yet, very few studies have focused on the potential positive effects of linear infrastructures such as railway verges on bats. Some bat species fly along such features when commuting from roosts to foraging areas because these linear elements could constitute commuting paths away from predators and wind (Limpens and Kapteyn 1991). In addition, some species forage regularly along linear elements (Verboom and Huitema 1997). Indeed, foraging activity is facilitated close to these features because of greater abundance of some preys (Verboom and Spoelstra 1999). These contrasting behaviours among species may be linked to their specific foraging ecology (Kerth and Melber 2009).

We hypothesized that railway verges impacted negatively some species, particularly gleaner species generally linked with forest habitat (such as species from the Myotis genus). These species could perceive railway verges as an inadequate habitat and in addition could be impacted by the fragmentation effect of these verges. Conversely, aerial hawking species that generally forage in more open habitats, such as species of the genus Pipistrellus, Nyctalus or Eptesicus, could benefit from the edge effect of railway verges, using them as a foraging/commuting habitat (Vandevelde et al. 2014).

To test this hypothesis, we examined the potential use by bats of railway verges crossing woodland patches within an agricultural matrix as foraging/commuting habitats. We tested whether (i) at a large scale (national level), railways lines were globally a preferred foraging/commuting habitat for these different common bats species, and (ii) at a local scale (landscape level), woodland-railway verges had an effect on bat activity compared to other habitat types like woodland-field verges, woodland habitats and field habitats. At local scale, we also tested the influence of landscape composition on bat activity over habitat types (Vandevelde et al. 2014).

We identified ten similar sites via aerial photographs and field visits: each site consisted of a railway portion of $600 \mathrm{~m}$ to $2 \mathrm{~km}$ long fragmenting a woodland patch within a farmland matrix. We used two distinct sets of data for bat calls. 'Local-scale' data from railway sites were sampled in the summer of 2010 following a similar protocol to the one designed for the French Bat Monitoring Programme (named Vigie-Chiro), from which we used 'large-scale' (national) data collected from 2006 to 2011. For both local- and large-scale data sets, bat calls were detected. Each point was monitored twice: once in the period between June 15 and 
July 31, during which females give birth and feed their offspring; second, in the period between August 15 and September 31, during which young are flying and individuals are expected to be less dependent on their reproductive roost. Habitat characteristics were analysed in a radius of $100 \mathrm{~m}$ around the sampled point, using a detailed habitat classification (Kerbiriou et al. 2010). Species calls were identified through spectrogram analyses.

At large scale, we found that activity of common bats in railway verges was of the same order of magnitude as in other habitats, except for aquatic habitats, which are known as key habitats for numerous European bat species (Russo and Jones 2003; Nicholls and Racey 2006). Furthermore, we found that activity was even greater in railway verges than in some other habitats for two aerial species: $N$. leislerii and $P$. pipistrellus. For $P$. pipistrellus, a very generalist species (Russ and Montgomery 2002), activity in railway verges was greater than in seven other habitats. Overall, bat activity among railway verges was not inferior to the activity in highly modified habitats such as continuous artificial surfaces, discontinuous artificial surfaces and arable land (confirmed for 4 of the 5 taxa studied).

At local scale, we found a negative effect of railway areas on the Myotis spp. for the two sample periods and a positive effect on Nyctalus spp. for the post-reproductive period. When focusing the analysis on the site type, we detected few obvious significant differences in bat activity between the verges of railways and the three other site types (field verges, plain field and plain wood). The significant difference for Nyctalus spp. during the post-reproductive period (lower activity in woods than on railway verges) may seem contradictory with the positive effect of surrounding areas of wood for these species at the same period. The foraging ecology of these aerial hawking bats and their habitat requirements could explain these results: Nyctalus spp. are species that forage mainly along edges, thus more in forest verges than in the heart of forests, but otherwise inhabit the interior of the forests, thus the amount of woodland habitat at the landscape level would have also an overall positive effect.

It must be noted that except for the Myotis spp. group in the reproductive period, we detected no difference between the verges of railways and those of fields. This result seems to indicate a similar functioning role for railway verges on bats as that of other linear verges, particularly on common aerial hawking bats (Verboom and Huitema 1997).

Our results suggest that the presence of railway verges does not influence significantly the foraging/commuting activity of common bats, except for species like those from the Myotis group, a group including mostly gleaner species, less generalist species (Dietz et al. 2007) and some threatened species (Temple and Terry 2009).

In several cases (for P. pipistrellus at global scale and for Nyctalus spp. at local scale), railway verges even seem to provide a significant habitat in intensive agricultural landscapes where semi-natural elements, in particular linear elements like hedgerows, tend to disappear. Railways, along with other artificial linear infrastructures, may thus contribute to maintaining common bat populations in such landscapes. 


\section{Orthoptera Along Railway Verges in an Urban Landscape}

Railway verges could potentially provide a habitat for Orthoptera in an urban landscape because the majority of these insects in Europe are grassland species and some occur at roadsides (Theuerkauf and Rouys 2006). We thus studied Tettigonidae along railway verges in urban landscapes using an original method. Because Orthoptera produce mating calls that are species-specific, it is possible to collect large standardised datasets using sound recording devices. To sample a large number of landscapes, we thus recorded Orthoptera sounds from running trains along five long-established railway lines in the Paris region (Penone et al. 2013). We did not sample the entire community of singing Orthoptera but rather focused on insects that produced powerful stridulations, which were not masked by the noise produced by trains.

We detected 2003 individuals of 10 species of bush-crickets from the Tettigoniidae family along $209 \mathrm{~km}$ of railway verges (Penone et al. 2013). This represented 59\% of Tettigoniidae species known to exist in the region (Voisin 2003) and included specialist species (e.g. Conocephalus fuscus). These results suggest that railway verges play a habitat role for these arthropods even for specialist species that are more heavily affected by anthropogenic changes. This was further strengthened by the fact that Orthoptera abundance was significantly lower when the trains crossed areas with paved (non vegetated) railway verges (Penone et al. 2013). We also detected a significant negative effect of urbanisation on species richness, abundance and community specialization, over a broad set of spatial scales (Penone et al. 2013). This effect was partly mitigated when railway verges were vegetated, suggesting that these zones are not only habitats but could even act as refugia for Orthoptera in an urban landscape. Therefore, if extensively managed (Marini et al. 2008), railway verges could play a role in the conservation of biodiversity in urban areas. More generally, we believe that acoustic surveys are a simple and cost-effective method, allowing long-term and large-scale surveys that can help advance railway ecology studies.

\section{Railways as Corridors in an Urban Landscape (Longitudinal Connectivity)}

Habitat fragmentation is a major perturbation that affects biodiversity at local, regional and global scales (Fahrig 2003; Krauss et al. 2010). Fragmentation has effects not only at the population level but also on taxonomic and functional composition of communities and on species interactions (Fahrig 2003; Fischer and Lindenmayer 2007; Krauss et al. 2010). Fragmented landscapes, including urban ones, are characterised by small habitat patches isolated by a matrix that filters species according to their mobility and dispersal abilities (Ewers and Didham 2006; Ricketts 2001). In this context, functional connectivity is crucial to maintain 
populations, communities and potentially, ecosystem services (Taylor et al. 1993). As shown before in this book, railways are mainly considered to be barriers for wildlife or corridors for invasive species. However, railways are linear and almost continuous patches of vegetation that penetrate into dense urban areas, ensuring a structural connectivity. Despite their potential as corridors, railway verges functional connectivity has been poorly studied (but see Tikka et al. 2001), and most studies have focussed on invasive species (Hansen and Clevenger 2005).

As mentioned previously, semi-natural grasslands are one of the vegetation types in railway verges, especially in urban contexts, where the space is precious and the verges have a reduced width. In general, semi-natural grasslands are important habitats for conservation because they support plants, invertebrates and vertebrates, including threatened ones, and provide ecosystem services (Ridding et al. 2015). However, surfaces are decreasing all around Europe, therefore it is crucial to conserve them and ensure connectivity between the patches to enhance gene and species flows. In our study (Penone et al. 2012), we examined whether these areas could provide functional connectivity for semi-natural grassland plants in urban landscapes.

\section{Using Structural Breaks to Detect Functional Connectivity Along Railways}

If linear structures provide functional connectivity an interruption of structure should result in an interruption of the function. The structural connectivity of railway verges is regularly interrupted by spatial breaks, such as overpasses and stations. We hypothesised that if railway verges favour connectivity, spatially connected communities within railway verges should be more similar than disconnected communities (H1). We tested this assumption by comparing floristic dissimilarities between sites located along railway verges that were either connected or separated by a railway break (Penone et al. 2012). In order to take into account differences among plant species, we considered species traits linked to dispersal abilities. These analyses were conducted on 71 plots located on two different railway lines going from Paris to the south of the Paris region (Fig. 16.1).

We found a significant effect of railway breaks on most species and dispersal traits consistent to our hypothesis (H1): connected communities were more similar than disconnected ones, suggesting a potential corridor role of railway verges (Penone et al. 2012). However, this effect was influenced by species mobility (summarized in Fig. 16.2). Highly mobile species (e.g. wind pollinated) were not affected by railway breaks, likely because they can disperse over long distances in any direction. Similarly, we did not find a significant effect of railway breaks on poorly mobile species (e.g. gravity-dispersed seeds). Their dispersal is more related to very local factors (e.g. slope) and the effect of breaks might be only visible over multiple generations. The most interesting result was found for moderately mobile species (e.g. wind-dispersed seeds), for which we found a significant effect of railway breaks. For these species railways seemed to provide functional 


\section{Highly mobile species}

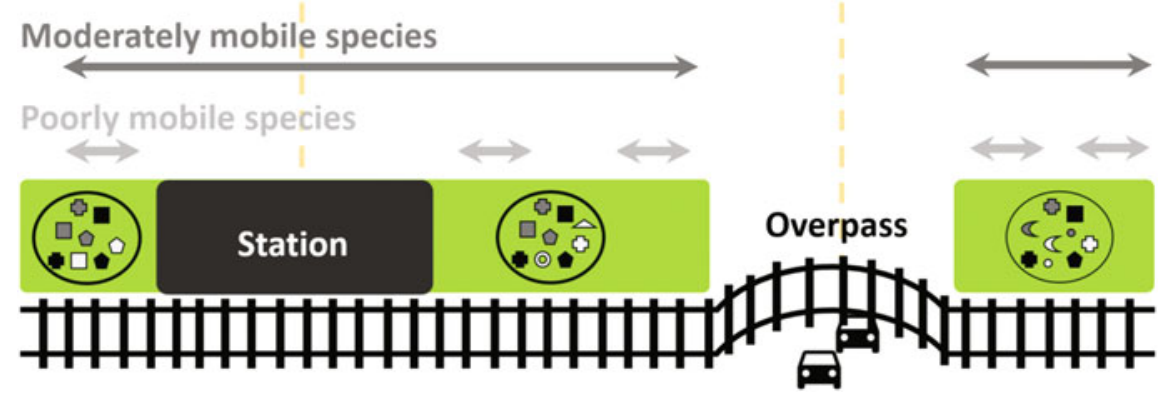

Fig. 16.2 Functional connectivity of railway verges for semi-natural plant species. Green patches represent railway verges. Arrows represent propagules movement. Circles with symbols represent plant communities with highly (black), moderately (dark grey) and poorly (light grey) mobile species

connectivity, at least between two railway breaks, which can represent large distances (e.g. more than $5 \mathrm{~km}$ in our study) (Penone et al. 2012).

Interestingly, we detected an effect of overpasses but not of stations on community dissimilarities (Penone et al. 2012 and Fig. 16.2). The slipstream of trains, which possibly carry wind-dispersed seeds (as shown for cars, Von der Lippe and Kowarik 2007), can be interrupted by air turbulence or crosswind when the trains traverse overpasses (Ernst 1998). Since those have very narrow paved verges, the seeds are more likely to be lost. The airflow may also be interrupted when trains slow down or stop at stations. But at stations, seeds may then be picked up again by air turbulence or wind. More generally, using structural connectivity to detect functional connectivity allows assessing corridor efficiency for several species groups. The precision is lower compared to genetic methods, which are the best suited methods for this purpose, but our methods are cost and time effective. Therefore, we believe that is an interesting and valuable cost-effective approach that can be widely applied to railway research to assess corridor efficiency in the future.

\section{Using Urbanisation Effects to Detect Functional Connectivity Along Railways}

Plant community composition is the result of stochastic effects as well as different biotic and abiotic processes, or filters, that select species with suitable functional traits from a species pool through dispersal and survival (Roy and de Blois 2006; Weiher and Keddy 1999; Williams et al. 2009). The effects of these processes are particularly strong in urban landscapes (Stenhouse 2004). The abiotic constraints in cities include higher temperatures and nitrogen deposition (McDonnell et al. 1997; Pellissier et al. 2008). Fragmentation and isolation in urban landscapes also have an 
effect on communities through habitat size reduction and dispersal limitation. All these effects should be reflected in communities' trait composition (Weiher and Keddy 1999). While the first abiotic effects (temperature, nitrogen), should not be influenced by connectivity between patches within urban landscapes, the seconds (fragmentation effects) should be attenuated if communities are connected. We used this assumption as a supplementary and indirect approach to assess functional connectivity in railway verges. We hypothesised that if railway verges favour connectivity this should attenuate the effect of fragmentation on plant communities (H2). We thus examined the effects of urbanisation on species richness, diversity and trait composition in railway verges and compared our results with the patterns described in literature. This study was conducted using the same data as the previous analysis, i.e. 71 plots on two lines.

We did not detect urbanisation effects on plant communities due to fragmentation (Penone et al. 2012). Indeed, we did not find significant relationships between urban cover and plant richness, diversity or dispersal traits, while most studies detected positive or negative effects, depending on urbanisation intensity (McKinney 2008). In contrast we found an effect of abiotic conditions linked to the urban landscape, which were consistent with the literature. For instance, we detected a positive effect of urbanisation on the abundance of species adapted to higher temperatures and nitrogen levels (Penone et al. 2012). These results matched our hypothesis $(\mathrm{H} 2)$ and thus further suggested that railway verges provide functional connectivity in urban landscapes for semi-natural grassland species.

\section{What About Exotic and Invasive Species?}

Our study showed that railway verges can play a positive role for semi-natural grassland plants in urban landscapes by connecting communities and potentially improving gene and species flow between communities (Penone et al. 2012). However, as showed in Chap. 5, railway verges can also be corridors for invasive species. In order to explore this topic in an urban context, we performed the same analyses described above (railway breaks and urbanisation effects) separately for exotic and invasive species (Penone et al. 2012). We also focussed on one particular invasive species, Senecio inaequidens, which is one of Europe's fastest plant invaders and is suspected to spread along railways (Lachmuth et al. 2010).

We detected a significant effect of railway breaks on community similarity in terms of exotic but not invasive species (the latter being a subset of the exotic). As for native plants, this effect was only observed for overpasses and not railway stations (Penone et al. 2012). In addition, we measured the similarity between plots in the two different railway lines, accounting for urbanisation effects. We also found a difference between the two lines for exotic but not for invasive species (Penone et al. 2012). According to our hypothesis (H1: if railways verges provide functional connectivity, structurally connected communities should be more similar than disconnected ones) this result suggests that railway verges might play a connectivity role for exotic but not for invasive species in urban landscapes. 
We also analysed the effects of urbanisation on the frequency of exotic and invasive plants to test our hypothesis $\mathrm{H} 2$ (urbanisation effects should be attenuated if communities are connected). We found the well-known positive urbanisation effect on exotic and invasive species, i.e., increased species frequency in highly urbanised areas (Penone et al. 2012). This result possibly suggests that the urbanisation effect was not attenuated by railways connectivity and thus railways did not provide additional functional connectivity for exotic and invasive species in urban landscapes.

To further confirm these results we performed a genetic analysis on S. inaequidens in the same region (Blanchet et al. 2014). This perennial herb presents a self-incompatible reproductive system and is pollinated by insects; the effective fruit production is high, with $75 \%$ viable achenes, which are well dispersed by wind and animals (Lopez-Garcia and Maillet 2005). This species was introduced in the south of France (Mazamet) in 1936 and then observed in Gare d'Austerlitz (a Parisian railway station) in 1990 (Henry and Maurin 1999). Consequently, we hypothesised that if railway verges play a corridor role for $S$. inaequidens, genetic diversity of this species should be structured along railways. We collected 450 individuals from 15 populations regularly on 3 different railway lines connecting the centre of Paris to its periphery. Given that the species was first seen in Parisian railway stations and assuming that railways act as corridors for $S$. inaequidens in the Parisian region, we expected a significant genetic differentiation among the main departure stations within Paris centre and among the three railway lines. We also expected significant isolation by distance (i.e., positive correlation between genetic distance and geographical distance) if the main central stations act as sources for other populations in the surroundings.

Our results did not confirm these scenarios: despite a clear differentiation among the three departure stations of the centre of Paris and a genetic cline along one of the lines, the differentiation among lines was low. Similarly, we did not detect significant isolation by distance among populations within lines, supporting the absence of population structure along railways (Blanchet et al. 2014). One explanation could lie in multiple sources of introduction of $S$. inaequidens from other European regions (e.g. Belgium or Germany). This species has high dispersal ability and is also present in other urban habitats (e.g. wastelands), which could also contribute to the high gene flow detected. In sum, the impact of railways as corridors on the genetic structure of $S$. inaequidens was not confirmed in our study, especially outside the centre of Paris where the deep interconnection with other corridors such as motorways in the suburban matrix may have a significant impact by reducing genetic differentiation among railway lines.

All the results that we put together converge and tend to suggest that in a highly urbanized and anthropogenic region, railway verges provide functional connectivity for exotic species but not for invasive species. This is inconsistent with many other studies on other transport networks (roadsides, highways), and should then been taken with care (but see Kalwij et al. 2008 for a similar result). Although railway verges did not appear as clear corridors for invasive species, trains might constitute an efficient transportation vector for seeds and contribute to their spread outside 
cities. Furthermore, railway verges are habitats and thus potential sources for these species for other habitats. The positive urbanisation effect that we found on these species, suggests that their presence is more linked to the urban context (sources, abiotic conditions) than railways connectivity. More studies are needed to assess railways connectivity in other landscapes and for a greater number of species.

\section{Railways as Barriers in an Agricultural Landscape (Transversal Connectivity)}

Linear infrastructures such as railways can be barriers to the movements of individuals and, hence, may have strong impacts on populations (see Chap. 4). We tested if this effect existed or if there was transversal connectivity between the two sides of a high-speed railway for the common butterfly Pyronia tithonus (Vandevelde et al. 2012). We hypothesised that $P$. tithonus individuals, if captured on the railway verge on one side of the railway and translocated to the other side in a similar habitat, will not be able to return to their original site because of the alleged barrier effect of the railroad. This hypothesis is based on empirical evidence that $P$. tithonus shows homing behaviour when displaced: when given a choice between a familiar and an unfamiliar habitat, these butterflies prefer to return to their familiar habitat (Conradt et al. 2001).

Pyronia tithonus is a European Satyrinae (Nymphalidae) occurring in several grassland habitats, usually in association with scrub or hedges. Mean life-span of adults ranges from 3.5 to 8 days (Brakefield 1987). P. tithonus produces only one generation per year and uses several grasses as host plants (Merckx and Van Dyck 2002).

We captured, marked and displaced 152 individuals in two different locations. One-third of the butterflies were released at a capture plot, one-third on the other side of the railway (in a similar habitat) and one-third on the same side but $100 \mathrm{~m}$ away from the capture plot. Many (31\%) butterflies crossed the railway, showing homing behaviour. There were even a slightly greater number of exchanges between the two release plots across the railway (12) than between the two release plots along the railway (8); the opposite of what we would expect if railways acted as a barrier to butterfly movements.

Even if based on a small sample, our results tend to show that contrary to wide busy roads (Munguira and Thomas 1992), high-speed railways, which are narrower and have infrequent traffic, are not barriers to Gatekeeper movements. These results also suggest that in a predominantly agricultural-intensive context, railways with large grassy verges could be substitution habitats for grassland butterflies, with no effect of the 20-m-wide-ballast-tracks. Furthermore, it suggests that passing trains do not have an impact on $P$. tithonus movements. However, the mortality risk from train traffic still has to be properly assessed, as well as the possible effects of the railway structure (tracks on cuttings vs. those on embankments; wide vs. narrow verges) on movements of individuals. 


\section{Conclusion}

In a context of rapid biodiversity decline, our results (see synthesis Table 16.1) suggest that railway verges should be considered by managers and engineers not only as a side aspect of the railroad, but also as elements having a potential role in maintaining common biodiversity, especially in human-dominated landscapes such as urban areas or agricultural systems. We found that railway verges could play habitat and corridor roles and that railways were not barriers for butterfly species. The total length of the railway network worldwide is more than one million kilometres (CIA 2008), and its verges represent important green areas (e.g. nearly $0.1 \%$ of the French surface). Therefore, the latter could represent an interesting topic for biodiversity conservation in human-dominated landscapes, as already suggested (Jarošík et al. 2011; Le Viol et al. 2008). More precisely, railway verges may contribute, along with private gardens and green spaces (Vergnes et al. 2012), to improve biodiversity in urban environments and could be potentially included in urban green network planning. Moreover, railway verges plants are mainly herbs and grasses that can be of interest for semi-natural grassland conservation, as already suggested for road verges (Cousins and Lindborg 2008).

In order to contribute to the maintenance of biodiversity, the management of these verges is thus crucial, as shown by previous studies (e.g. Noordijk et al. 2010). The following management rules should be considered: (1) during the construction phase, the revegetation process should try to maximise plant diversity to increase interactions with higher trophic levels as well as ecosystem functioning, (2) the relationship between the network of these linear features and the overall landscape connectivity should be considered (Karim and Mallik 2008; Boughey et al. 2011), (3) finally, during the exploitation phase of the railroad, management decisions could take biodiversity into account through a move from clearcutting to more extensive management (e.g. selected cutting and late-mowing), enabling the maintenance of some linear structures and allowing the reproduction of several plant and insect species.

Table 16.1 The three roles of railway verges studied on selected taxa

\begin{tabular}{l|l|l|l}
\hline & Habitat & $\begin{array}{l}\text { Longitudinal } \\
\text { connectivity }\end{array}$ & $\begin{array}{l}\text { Transversal } \\
\text { connectivity }\end{array}$ \\
\hline Bats & $\begin{array}{l}\text { Generalist species: yes } \\
\text { Specialist species: no }\end{array}$ & nt & nt \\
\hline Orthoptera & Yes & nt & nt \\
\hline Plants & Yes & Yes & nt \\
\hline $\begin{array}{l}\text { Invasive species } \\
(\text { S. inaequidens })\end{array}$ & Yes & Not detected & Possible \\
\hline $\begin{array}{l}\text { Common butterfly } \\
(P . \text { tithonus })\end{array}$ & $\mathrm{nt}$ & $\mathrm{nt}$ & Yes \\
\hline
\end{tabular}

$n t$ not tested 
Overall, we suggest that extensive management coupled with small-scale revegetation processes, either artificial or natural, may help counteract the negative large-scale effects of urbanisation and of the homogenisation of agricultural landscapes.

Acknowledgements We deeply thank the editors for inviting us to participate to this stimulating book on railway ecology. We would also like to thank in particular L. Borda de Água as well as I. Takehito for their constructive and helpful comments on the submitted version of this chapter.

\section{References}

Abbott, I. M., Butler, F., \& Harrison, S. (2012). When flyways meet highways-The relative permeability of different motorway crossing sites to functionally diverse bat species. Landscape and Urban Planning, 106, 293-302.

Bach, L., Burkhardt, P., \& Limpens, H. J. (2004). Tunnels as a possibility to connect bat habitats. Mammalia, 68, 411-420.

Berthinussen, A., \& Altringham, J. (2012). The effect of a major road on bat activity and diversity. Journal of Applied Ecology, 49, 82-89.

Blanchet, É., Penone, C., Maurel, N., Billot, C., Rivallan, R., Risterucci, A.-M., et al. (2014). Multivariate analysis of polyploid data reveals the role of railways in the spread of the invasive South African Ragwort (Senecio inaequidens). Conservation Genetics, 16, 523-533.

Boughey, K. L., Lake, I. R., Haysom, K. A., \& Dolman, P. M. (2011). Improving the biodiversity benefits of hedgerows: How physical characteristics and the proximity of foraging habitat affect the use of linear features by bats. Biological Conservation, 144, 1790-1798.

Brakefield, P. M. (1987). Geographical variability in, and temperature effects on, the phenology of Maniola jurtina and Pyronia tithonus (Lepidoptera, Satyrinae) in England and Wales. Ecological Entomology, 12, 139-148.

Central Intelligence Agency. (2008). Transportation. In The world factbook.

Conradt, L., Roper, T. J., \& Thomas, C. D. (2001). Dispersal behaviour of individuals in metapopulations of two British butterflies. Oikos, 95, 416-424.

Cousins, S. A. O., \& Lindborg, R. (2008). Remnant grassland habitats as source communities for plant diversification in agricultural landscapes. Biological Conservation, 141, 233-240.

Dietz, C. Von, Helversen, O., \& Nill, D. (2007). Handbuch der Fledermäuse Europas und Nordwestafrikas. Stuttgart: Franckh-Kosmos Verlag.

Ernst, W. H. O. (1998). Invasion, dispersal and ecology of the South African neophyte Senecio inaequidens in The Netherlands: From wool alien to railway and road alien. Acta Botanica Neerlandica, 47, 131-151.

Ewers, R. M., \& Didham, R. K. (2006). Confounding factors in the detection of species responses to habitat fragmentation. Biological Reviews, 81, 117-142.

Fahrig, L. (2003). Effects of habitat fragmentation on biodiversity. Annual Review of Ecology Evolution and Systematics, 34, 487-515.

Fischer, J., \& Lindenmayer, D. B. (2007). Landscape modification and habitat fragmentation: A synthesis. Global Ecology and Biogeography, 16, 265-280.

Forman, R. T., Sperling, D., Bissonette, J. A., Clevenger, A. P., Cutshall, C. D., Dale, V. H., et al. (2002). Road ecology: Science and solutions. Washington, DC: Island Press.

Hansen, M. J., \& Clevenger, A. P. (2005). The influence of disturbance and habitat on the presence of non-native plant species along transport corridors. Biological Conservation, 125, 249-259.

Henry, H.-P., \& Maurin, H. (1999). Les inventaires du patrimoine naturel en milieu urbain [The inventories of the natural heritage in urban environments]. In B. Lizet, A.-E. Wolf, \& J. Celecia (Eds.), Sauvages dans la ville. De l'inventaire naturaliste à l'écologie urbaine [Wild in the city. 
From naturalist inventories to urban ecology] (pp. 333-355). Paris: Publications scientifiques du Muséum.

Hodkinson, D. J., \& Thompson, K. (1997). Plant dispersal: The role of man. Journal of Applied Ecology, 34, 1484-1496.

Jarošík, J., Konvička, M., Pyšek, P., Kadlec, T., \& Beneš, J. (2011). Conservation in a city: Do the same principles apply to different taxa? Biological Conservation, 144, 490-499.

Kalwij, J. M., Milton, S. J., \& McGeoch, M. A. (2008). Road verges as invasion corridors? A spatial hierarchical test in an arid ecosystem. Landscape Ecology, 23, 439-451.

Karim, M. N., \& Mallik, A. U. (2008). Roadside revegetation by native plants: I. Roadside microhabitats, floristic zonation and species traits. Ecological Engineering, 32, 222-237.

Kerbiriou, C., Bas, Y., Dufrêne, L., Robert, A., \& Julien, J. F. (2010). Long term trends monitoring of bats, from biodiversity indicator production to species specialization assessment. Paper presented at the 24th Annual Meeting of the Society for Conservation Biology, Edmonton, Canada.

Kerth, G., \& Melber, M. (2009). Species-specific barrier effects of a motorway on the habitat use of two threatened forest-living bat species. Biological Conservation, 142, 270-279.

Krauss, J., Bommarco, R., Guardiola, M., Heikkinen, R. K., Helm, A., Kuussaari, M., et al. (2010). Habitat fragmentation causes immediate and time-delayed biodiversity loss at different trophic levels. Ecology Letters, 13, 597-605.

Lachmuth, S., Durka, W., \& Schurr, F. M. (2010). The making of a rapid plant invader: Genetic diversity and differentiation in the native and invaded range of Senecio inaequidens. Molecular Ecology, 19, 3952-3967.

Lesinski, G., Olszewski, A., \& Popczyk, B. (2011). Forest roads used by commuting and foraging bats in edge and interior zones. Polish Journal of Ecology, 59, 611-616.

Le Viol, I., Julliard, R., de Kerbiriou, C., Redon, L., Carnino, N., Machon, N., et al. (2008). Plant and spider communities benefit differently from the presence of planted hedgerows in highway verges. Biological Conservation, 141, 1581-1590.

Limpens, H., \& Kapteyn, K. (1991). Bats, their behaviour and linear landscape elements. Myotis, 29, 39-48.

Lopez-Garcia, M. C., \& Maillet, J. (2005). Biological characteristics of an invasive South African species. Biological Invasions, 7, 181-194.

Marini, L., Fontana, P., Scotton, M., \& Klimek, S. (2008). Vascular plant and Orthoptera diversity in relation to grassland management and landscape composition in the European Alps. Journal of Applied Ecology, 45, 361-370.

McDonnell, M. J., Pickett, S. T. A., Groffman, P., Bohlen, P., Pouyat, R. V., Zipperer, W. C., et al. (1997). Ecosystem processes along an urban-to-rural gradient. Urban Ecosystems, 1, 21-36.

McKinney, M. (2008). Effects of urbanization on species richness: A review of plants and animals. Urban Ecosystems, 11, 161-176.

MEA. (2005). Ecosystems and human well-being. Washington, DC: Island Press.

Merckx, T., \& Van Dyck, H. (2002). Interrelations among habitat use, behavior, and flight-related morphology in two cooccurring satyrine butterflies, Maniola jurtina and Pyronia tithonus. Journal of Insect Behavior, 15, 541-561.

Merriam, G., \& Lanoue, A. (1990). Corridor use by small mammals: Field measurement for three experimental types of Peromyscus leucopus. Landscape Ecology, 4, 123-131.

Munguira, M. L., \& Thomas, J. A. (1992). Use of road verges by butterfly and burnet populations, and the effect of roads on adult dispersal and mortality. Journal of Applied Ecology, 29, 316-329.

Nicholls, B., \& Racey, P. A. (2006). Habitat selection as a mechanism of resource partitioning in two cryptic bat species Pipistrellus pipistrellus and Pipistrellus pygmaeus. Ecography, 29, 697-708.

Noordijk, J., Schaffers, A. P., Heijerman, T., Boer, P., Gleichman, M., \& Sýkora, K. V. (2010). Effects of vegetation management by mowing on ground-dwelling arthropods. Ecological Engineering, 36, 740-750. 
O'Farrell, P. J., \& Milton, S. J. (2006). Road verge and rangeland plant communities in the southern Karoo: Exploring what influences diversity, dominance and cover. Biodiversity and Conservation, 15, 921-938.

Pellissier, V., Roze, F., Aguejdad, R., Quenol, H., \& Clergeau, P. (2008). Relationships between soil seed bank, vegetation and soil fertility along an urbanisation gradient. Applied Vegetation Science, 11, 325-334.

Penone, C., Kerbiriou, C., Julien, J.-F., Julliard, R., Machon, N., \& Le Viol, I. (2013). Urbanisation effect on Orthoptera: Which scale matters? Insect Conservation and Diversity, 6, 319-327.

Penone, C., Machon, N., Julliard, R., \& Le Viol, I. (2012). Do railway edges provide functional connectivity for plant communities in an urban context? Biological Conservation, 148, 126-133.

Ricketts, T. H. (2001). The matrix matters: Effective isolation in fragmented landscapes. The American Naturalist, 158, 87-99.

Ridding, L. E., Redhead, J. W., \& Pywell, R. F. (2015). Fate of semi-natural grassland in England between 1960 and 2013: A test of national conservation policy. Global Ecology and Conservation, 4, 516-525.

Ries, L., Debinski, D. M., \& Wieland, M. L. (2001). Conservation value of roadside prairie restoration to butterfly communities. Conservation Biology, 15, 401-411.

Roy, V., \& de Blois, S. (2006). Using functional traits to assess the role of hedgerow corridors as environmental filters for forest herbs. Biological Conservation, 130, 592-603.

Russ, J. M., \& Montgomery, W. I. (2002). Habitat associations of bats in Northern Ireland: Implications for conservation. Biological Conservation, 108, 49-58.

Russo, D., \& Jones, G. (2003). Use of foraging habitats by bats in a Mediterranean area determined by acoustic surveys: Conservation implications. Ecography, 26, 197-209.

Saarinen, K., Valtonen, A., Jantunen, J., \& Saarnio, S. (2005). Butterflies and diurnal moths along road verges: Does road type affect diversity and abundance? Biological Conservation, 123, 403-412.

Stenhouse, R. N. (2004). Fragmentation and internal disturbance of native vegetation reserves in the Perth metropolitan area, Western Australia. Landscape and Urban Planning, 68, 389-401.

Taylor, P. D., Fahrig, L., Henein, K., \& Merriam, G. (1993). Connectivity is a vital element of landscape structure. Oikos, 68, 571-573.

Temple, H. J., \& Terry, A. (2009). The status and distribution of european mammals. Luxembourg: Office for Official Publications of the European Communities.

Theuerkauf, J., \& Rouys, S. (2006). Do Orthoptera need human land use in Central Europe? The role of habitat patch size and linear corridors in the Biaowieza forest, Poland. Biodiversity and Conservation, 15, 1497-1508.

Tikka, P. M., Hogmander, H., \& Koski, P. S. (2001). Road and railway verges serve as dispersal corridors for grassland plants. Landscape Ecology, 16, 659-666.

Vandevelde, J.-C., Bouhours, A., Julien, J.-F., Couvet, D., \& Kerbiriou, C. (2014). Activity of European common bats along railway verges. Ecological Engineering, 64, 49-56.

Vandevelde, J.-C., Penone, C., \& Julliard, R. (2012). High-speed railways are not barriers to Pyronia tithonus butterfly movements. Journal of Insect Conservation, 16, 801-803.

Verboom, B., \& Huitema, H. (1997). The importance of linear landscape elements for the pipistrelle Pipistrellus pipistrellus and the serotine bat Eptesicus serotinus. Landscape Ecology, $12,117-125$.

Verboom, B., \& Spoelstra, K. (1999). Effects of food abundance and wind on the use of tree lines by an insectivorous bat, Pipistrellus pipistrellus. Canadian Journal of Zoology, 77, 1393 1401.

Vergnes, A., Le Viol, I., \& Clergeau, P. (2012). Green corridors in urban landscapes affect the arthropod communities of domestic gardens. Biological Conservation, 145, 171-178.

Voisin, J. F. (2003). Atlas des Orthoptères et des Mantides de France [Atlas of French Orthoptera and Mantis of France]. Paris: MNHN, Collection Patrimoines Naturels. 
Von der Lippe, M., \& Kowarik, I. (2007). Long-distance dispersal of plants by vehicles as a driver of plant invasions. Conservation Biology, 21, 986-996.

Wehling, S., \& Diekmann, M. (2009). Importance of hedgerows as habitat corridors for forest plants in agricultural landscapes. Biological Conservation, 142, 2522-2530.

Weiher, E., \& Keddy, P. (1999). Assembly rules as general constraints on community composition. In E. Weiher \& P. Keddy (Eds.), Ecological assembly rules (pp. 251-271). Cambridge: Cambridge University Press.

Williams, N. S. G., Schwartz, M. W., Vesk, P. A., McCarthy, M. A., Hahs, A. K., Clemants, S. E., et al. (2009). A conceptual framework for predicting the effects of urban environments on floras. Journal of Ecology, 97, 4-9.

Open Access This chapter is licensed under the terms of the Creative Commons Attribution 4.0 International License (http://creativecommons.org/licenses/by/4.0/), which permits use, sharing, adaptation, distribution and reproduction in any medium or format, as long as you give appropriate credit to the original author(s) and the source, provide a link to the Creative Commons license and indicate if changes were made.

The images or other third party material in this chapter are included in the chapter's Creative Commons license, unless indicated otherwise in a credit line to the material. If material is not included in the chapter's Creative Commons license and your intended use is not permitted by statutory regulation or exceeds the permitted use, you will need to obtain permission directly from the copyright holder. 